\title{
Cellulolytic Bacteria in some Ruminants and Herbivores as Shown by Fluorescent Antibody
}

\author{
BY M. ELIZABETH DAVIES \\ Royal (Dick) School of Veterinary Studies, University of Edinburgh
}

(Received 16 November 1964)

SUMMARY

A method is described for the demonstration and enumeration in situ of antigenically related cellulolytic bacteria in the intestinal contents of some herbivores and ruminants, by means of a fluorescent antibody staining technique.

\section{INTRODUCTION}

A comprehensive study of cellulolytic bacteria from the ruminant has been made by many workers in recent years (Hungate, 1950); much less attention has been paid to the same group of organisms in simple stomach herbivores and omnivores. Because of the technical difficulties involved in the isolation and identification of cellulolytic bacteria, an attempt has been made to demonstrate their presence in colon contents of pig, rabbit, guinea pig, sheep and bovine by the use of fluorescent antibody and to determine whether similar or antigenically related types were present in both ruminants and herbivores.

\section{METHODS}

Antisera. These were prepared in rabbits by intravenous injection of living cultures of four different types of cellulolytic bacteria isolated from the horse. Three of these organisms were Gram-negative bacilli belonging to the genus Bacteroides, and the fourth was a Gram-negative coccus (Davies, 1964). The bacilli were designated I, II and III and the coccus IV.

Washed bacteria suspended in normal saline to give about 1700 million organisms/ $\mathrm{ml}$. were used for a series of ten injections of $0.25 \mathrm{ml}$. each, given over a period of 4 weeks. Agglutination tests with homologous organisms showed that the titres of the antisera were low, ranging from $1 / 120$ to $1 / 960$.

Fluorescent staining. This was done by the indirect method, by using the prepared rabbit antiserum and Bacto (Difco) fluorescent goat anti-rabbit globulin. After rehydration according to the manufacturers' instructions, it was found advantageous to dialyse the fluorescent globulin against $200 \mathrm{ml}$. Coons buffered saline (Coons \& Kaplan, 1950) kept in the refrigerator for 6 days. This removed any free fluorescein released by dissociation. The dialysed antibody was absorbed with Bacto (Difco) mouse liver powder (Hobson \& Mann, 1957) immediately before use.

Rhodamine B 200, conjugated with bovine serum albumin (Nairn, 1962) was used as an intermediate stain to provide a background contrast.

Preparation of test slides. Samples of caecum, colon and rumen contents taken 
from freshly killed animals, were diluted one part by weight in ten parts of Coons saline. Smears were made on thin $(0.8 \mathrm{~mm}$.) glass slides, allowed to dry in air, and fixed by gentle heat. Each of the antisera was diluted 1/100 in Coons saline to minimize background fluorescence, and layered over the prepared smears, which were then incubated at $39^{\circ}$ for $30 \mathrm{~min}$. in closed Coplin staining jars. They were stained first with rhodamine $\mathbf{B}$ and then with fluorescein conjugates, for $\mathbf{3 0} \mathrm{min}$. periods, being washed for $10 \mathrm{~min}$. in two changes of Coons buffered saline between each stage of staining. The smears were blotted, mounted in Bacto (Difco) FA mounting fluid, with ordinary coverslips, and examined for fluorescent bacteria by dark-field illumination, with a 250-watt high-pressure mercury arc light. Controls used to establish the validity of the technique consisted of smears of the samples treated with normal instead of immune serum, and stained with fluorescent conjugates, and of other smears stained with the fluorescent conjugates without previous treatment with serum. Smears of the organisms I-IV, treated with their homologous antiserum and stained with the fluorescent conjugates, were included in every set of samples examined.

Counts of organisms I, II, III and IV were made as follows. Suspensions of gut contents were prepared by diluting one part by weight in ten parts Coons saline, and volumes of $\mathbf{0 . 0 0 1} \mathrm{ml}$. were dropped on to slides from a micrometer syringe (Agla; Burroughs Wellcome). These drops were stained and mounted as above, and the fluorescent bacteria present in the whole drop were then counted.

\section{RESULTS}

Each of the four organisms used for preparing antisera was examined for fluorescence with antisera to the other three, and it was found that organisms I and II possessed a common antigen. Organisms II, III and IV also shared some antigens, but differed from each other and from organism $\mathrm{I}$.

Table 1. Occurrence of four types of cellulolytic bacteria in five animal species

\begin{tabular}{|c|c|c|c|c|c|c|c|c|}
\hline \multirow[b]{3}{*}{ Organism } & \multicolumn{8}{|c|}{ Animal species } \\
\hline & \multicolumn{2}{|c|}{ Rabbit (10) } & \multicolumn{2}{|c|}{ Guinea pig (10) } & \multicolumn{2}{|c|}{ Pig (12) } & \multirow{2}{*}{$\begin{array}{c}\text { Cattle } \\
\text { (10) } \\
\text { Rumen }\end{array}$} & \multirow{2}{*}{$\begin{array}{c}\text { Sheep } \\
\text { (10) } \\
\text { Rumen }\end{array}$} \\
\hline & Caecum & Colon & Caecum & Colon & Caecum & Colon & & \\
\hline $\mathbf{I}$ & $\mathbf{5}$ & 6 & $\mathbf{3}$ & 4 & 9 & 7 & 7 & $\mathbf{5}$ \\
\hline II & 5 & 7 & 5 & 7 & 8 & 10 & 6 & 4 \\
\hline III & 4 & $\mathbf{5}$ & 7 & 2 & 9 & 6 & $\boldsymbol{9}$ & 4 \\
\hline IV & 5 & 4 & 6 & 4 & 8 & 9 & $\boldsymbol{9}$ & $\mathbf{5}$ \\
\hline
\end{tabular}

Figures in parentheses indicate the number of animals examined.

The number of organisms/g. sample varied; the average value for the six animals being 3.5 million for organism I; 4.7 million for organism II; 15.0 million for organism III and 17.0 million for organism IV. In all cases therefore the numbers exceeded the minimum of 1 million/g. postulated by Gall \& Huhtanen (1951) as a criterion of significance for organisms in the rumen.

Samples from the caecum and colon of ten rabbits, ten guinea pigs and twelve 
pigs and from the rumen of ten cattle and ten sheep were examined for fluorescent bacteria. The number of times each organism was found in samples from the different animal species is shown in Table 1.

These results showed that fluorescent antibody technique could be used satisfactorily to study the distribution of cellulolytic bacteria in the intestinal contents of different animal species. They also indicated that the four antigenic types isolated from the horse, or others very closely related antigenically to them, were present in the large intestine of the other animal species investigated.

The technique could also be applied to the enumeration of individual bacterial species in colon samples, although as with other counting methods, considerable variation was found in the numbers of each species in the colon contents of different animals. This method would appear to have the advantage of accounting for the 'fixed' as well as the 'free' bacteria present in any sample. In his monograph Oxford (1964), stated that most counting methods so far used have not taken into account the fixed organisms (those closely attached to plant fibres) which may be the most important. The method would also allow counts to be made of any one species without the difficulties of culture.

The author wishes to thank Drs P. N. Hobson and D. M. Weir for helpful advice on the assembly and use of the ultraviolet microscope.

\section{REFERENCES}

Coons, A. H. \& KAPLAN, M. H. (1950). Improvements in a method for the detection of antigens by means of fluorescent antibody. J. exp. Med. 91, 1.

Davies, M. E. (1964). Cellulolytic bacteria isolated from the large intestine of the horse. J. appl. Bact. 3, 373.

Gall, L. S. \& Huhtanen, C. N. (1951). Criteria for judging a true rumen organism and a description of five rumen bacteria. J. Dairy Sci. 34, 353 .

Hobson, P. N. \& MaNN, S. O. (1957). Some studies on the identification of rumen bacteria with fluorescent antibodies. J. gen. Microbiol. 16, 463.

Hungate, R. E. (1950). The anaerobic mesophilic cellulolytic bacteria. Bact. Rev. 14, 1.

NaIRN, R. C. (1962). Fluorescent Protein Tracing. Livingstone Ltd., Edinburgh and London.

OXforD, A. E. (1964). A guide to rumen microbiology. Bulletin 160, New Zealand Department of Scientific and Industrial Research. 